\title{
X-linked cone dysfunction syndrome with myopia
}

INSERM

\section{Source}

INSERM. (1999). Orphanet: an online rare disease and orphan drug data base. $\underline{X-l i n k e d}$ cone dysfunction syndrome with myopia. ORPHA:90001

X-linked cone dysfunction syndrome with myopia is characterised by moderate to high myopia associated with astig matism and deuteranopia. Less than 10 families have been described so far. Transmission is X-linked recessive and the locus has been mapped to Xq28. 